\title{
Spectrophotometric Determination of Trace Amounts of Scandium with Molybdate, Nile Blue and Poly(vinyl alcohol)
}

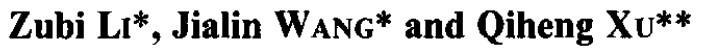 \\ *Adult Education College, Yunnan University, Kunming 650091, People's Republic of China \\ ** Department of Chemistry, Yunnan University, Kunming 650091, People's Republic of China
}

\begin{abstract}
A sensitive method for the determination of trace amounts of scandium by spectrophotometry is described, based on the formation of the ion associate between scandium(III), molybdate and Nile Blue in the presence of poly(vinyl alcohol). The molar absorptivity at $585 \mathrm{~nm}$ is $3.59 \times 10^{5} \mathrm{dm}^{3} \mathrm{~mol}^{-1} \mathrm{~cm}^{-1}$. Beer's law is obeyed over the range $0-2.0 \mu \mathrm{g}$ scandium per $25 \mathrm{ml}$. Optimal conditions for the determination and the interferences from foreign ions are reported. Ten-fold amounts of rare earth elements do not interfere with the determination of scandium, except cerium. The proposed method has been applied successfully for the spectrophotometric determination of scandium in some geological samples.
\end{abstract}

Keywords Scandium, molybdate, Nile Blue, spectrophotometry

Although many chromogenic reagents such as Xylenol Orange', Arsenazo $\mathrm{III}^{2}$, Eriochrome Azurol $\mathbf{B}^{3}$, Chromazurol S4, Chlorophosphonazo-p-Cl5, 2-(5-bromo-2pyridylazo)-5-diethylaminophenol ${ }^{6}, 4,5$-dibromophenylfluorone $e^{7}$ and Methylthymol Blue ${ }^{8}$ have been utilized for the spectrophotometric measurement of scandium, their sensitivities are low (molar absorptivity $1.9 \times 10^{4}-2.5 \times$ $\left.10^{5} \mathrm{dm}^{3} \mathrm{~mol}^{-1} \mathrm{~cm}^{-1}\right)$. Recently, the spectrophotometric determinations of niobium ${ }^{9}$, zirconium ${ }^{10}$, gold ${ }^{11}$, palladium $^{12}$ and platinum ${ }^{13}$ as the ion-association complexes of the metal ion-molybdate complexes and some basic dyes in aqueous solution in the presence of PVA have been reported. However, the possibility of the spectrophotometric determination of scandium using an ionassociation complex of this type has not been studied before. In this paper, the conditions for color development, the composition of the ion-association complex and the influence of foreign ions are reported. The method has been developed for the spectrophotometric determination of trace amounts of scandium. Its sensitivity is the highest at the present time and the selectivity is fairly good.

\section{Experimental}

\section{Apparatus}

Absorbance measurements were carried out on a Model 721A spectrophotometer (Sichuan Analytical Instrument Factory, China). A Model S-3C pH meter (Shanghai Analytical Instrument Factory NO 2, China) was used for $\mathrm{pH}$ measurements. A Shimadzu IR-450S was used for infra-red absorbance measurements.

\section{Reagents}

Standard scandium(III) solution $\left(100 \mu \mathrm{g} \mathrm{ml}^{-1} \mathrm{Sc}\right)$ : scandium oxide, $\mathrm{Sc}_{2} \mathrm{O}_{3}$ (Specpure) $(0.077 \mathrm{~g})$, was dissolved in $10 \mathrm{ml}$ of $6 \mathrm{~mol} \mathrm{dm}^{-3}$ hydrochloric acid and the solution was evaporated to remove the excess of acid. The salts were dissolved and diluted to $500 \mathrm{ml}$ with $5 \%$ (v/v) hydrochloric acid. A working solution was prepared by diluting this solution with distilled water.

Molybdate solution $\left(0.01 \mathrm{~mol} \mathrm{dm}^{-3}\right)$ : ammonium heptamolybdate, $\left(\mathrm{NH}_{4}\right)_{6}\left(\mathrm{Mo}_{7} \mathrm{O}_{24}\right) \cdot 4 \mathrm{H}_{2} \mathrm{O}(1.0 \mathrm{~g})$, was dissolved in distilled water to give a $500 \mathrm{ml}$ solution.

Nile Blue (NB) solution $\left(6.9 \times 10^{-4} \mathrm{~mol} \mathrm{dm}^{-3}\right)$ : Nile Blue (CI 51180) $(0.5 \mathrm{~g})$ was dissolved in distilled water to give a $100 \mathrm{ml}$ solution. A working solution was prepared by diluting this solution to $1 \mathrm{dm}^{3}$ with distilled water.

Perchloric acid $\left(5.8 \mathrm{~mol} \mathrm{dm}^{-3}\right)$ : commercially available concentrated perchloric acid $\left(70 \%, 11.6 \mathrm{~mol} \mathrm{dm}^{-3}\right)$ was used after dilution with distilled water.

Poly(vinyl alcohol) (PVA) solution $(2 \%, w / v)$ : commercially available PVA (number-averaged degree of polymerization, $2400-2500)(4.0 \mathrm{~g})$ was dissolved in distilled water to give $200 \mathrm{ml}$ of solution.

PMBP-petroleum ether saturated solution: 1-phenyl3-methylbenzoylpyrazoline-5-one (PMBP) $(0.6 \mathrm{~g})$ was dissolved in $200 \mathrm{ml}$ of petroleum ether, then the solution was stored in a brown glass bottle and allowed to stand overnight. The solution was used after filtering.

Buffer solution ( $\mathrm{pH}$ 5.5): buffer solution was prepared by using $0.1 \mathrm{~mol} \mathrm{dm}^{-3}$ sodium acetate and $0.1 \mathrm{~mol} \mathrm{dm}^{-3}$ acetic acid solution. This was stored in a glass bottle.

Formic acid solution ( $\mathrm{pH}$ 1.9): formic acid solution $(5 \%, \mathrm{v} / \mathrm{v})$ adjusted its $\mathrm{pH}$ to 1.9 with $1 \mathrm{~mol} \mathrm{dm}^{-3}$ hydrochloric acid was used. It was stored in a glass bottle.

All solutions were prepared with analytical reagent grade chemicals and kept in polyethylene bottles unless 
otherwise stated.

\section{Procedure}

Take a sample solution containing up to $2.0 \mu \mathrm{g}$ of scandium in a $25-\mathrm{ml}$ volumetric flask, add $1.5 \mathrm{ml}$ of $0.01 \mathrm{~mol} \mathrm{dm}^{-3}$ ammonium heptamolybdate solution, dilute to about $10 \mathrm{ml}$ with water and $\mathrm{mix}$. Heat in a boiling water bath for $30 \mathrm{~min}$, then cool to room temperature with flowing water. In the following order, add $5.0 \mathrm{ml}$ of $5.8 \mathrm{~mol} \mathrm{dm}^{-3}$ perchloric acid, $1.0 \mathrm{ml}$ of $2 \%$ (w/v) PVA and $2.0 \mathrm{ml}$ of $6.9 \times 10^{-4} \mathrm{~mol} \mathrm{dm}^{-3} \mathrm{NB}$ solution, then dilute to the mark with water and mix. After $20 \mathrm{~min}$, measure the absorbance of the solution in a $1-\mathrm{cm}$ quartz cell at $585 \mathrm{~nm}$, against a reagent blank.

\section{Preparation of geological sample solution}

Weigh $1-1.5 \mathrm{~g}$ of sample in a corundum crucible in which $0.5 \mathrm{~g}$ of sodium carbonate had been put, add $4-5 \mathrm{~g}$ sodium dioxide and fuse at $973 \mathrm{~K}$ for $15 \mathrm{~min}$. After cooling, transfer the crucible into a $250-\mathrm{ml}$ beaker and add $30 \mathrm{ml}$ of $50 \%(\mathrm{v} / \mathrm{v})$ triethanolamine, $4 \mathrm{ml}$ of $5 \%(\mathrm{w} /$ v) EDTA and $4 \mathrm{ml}$ of $30 \%(\mathrm{v} / \mathrm{v})$ hydrogen peroxide, then heat moderately to soak out. Wash the crucible with $60 \mathrm{ml}$ of hot water, filter the solution and wash the residue four times with $2 \%(\mathrm{w} / \mathrm{v})$ sodium hydroxide solution. Dissolve the residue with $10 \mathrm{ml}$ of $6 \mathrm{~mol} \mathrm{dm}^{-3}$ hot hydrochloric acid and wash filter paper with hot water, then concentrate the solution to about $5 \mathrm{ml}$.

Transfer this solution to a 60-ml separating funnel, add $4 \mathrm{ml}$ of $20 \%(\mathrm{w} / \mathrm{v})$ sulfosalicylic acid, $10 \mathrm{mg}$ of ascorbic acid and 1 drop of $0.1 \%(w / v)$ Methyl Orange solution, adjust the color of the solution to orange with $7 \mathrm{~mol}$ $\mathrm{dm}^{-3}$ ammonia, then add $3 \mathrm{ml}$ of buffer solution ( $\mathrm{pH} 5.5$ ), $1 \mathrm{ml}$ of isopentyl alcohol and $15 \mathrm{ml}$ of PMBP-petroleum ether solution. After shaking for $1 \mathrm{~min}$, slowly discard the aqueous phase, then wash the organic phase two times with water. Add $10 \mathrm{ml}$ of formic acid solution (pH 1.9) to the organic phase and shake the container for $1 \mathrm{~min}$. Discard the aqueous phase and add $15 \mathrm{ml}$ of hydrochloric acid solution (a mixture of $3.5 \mathrm{ml}$ of $4 \mathrm{~mol} \mathrm{dm}^{-3}$ hydrochloric acid and $11.5 \mathrm{ml}$ of water), then shake for $1 \mathrm{~min}$. Transfer the aqueous phase into a small beaker, then evaporate the solution to incipient dryness and cool to room temperature. Dissolve the salts with $0.5 \%(\mathrm{v} / \mathrm{v})$ hydrochloric acid, then transfer the solution to a $10-\mathrm{ml}$ volumetric flask and dilute to the mark with $0.5 \%(\mathrm{v} / \mathrm{v})$ hydrochloric acid. Take an appropriate volume in a $25-\mathrm{ml}$ volumetric flask and follow the procedure for the determination of scandium.

\section{Results and Discussion}

\section{Absorption spectra}

The absorption spectra of the reagent and the complex in the respective acids were recorded in the wavelength range $450-700 \mathrm{~nm}$ against the water and reagent blank, respectively. Figure 1 shows that the maximum absorption of the ion-association complexes of scandium

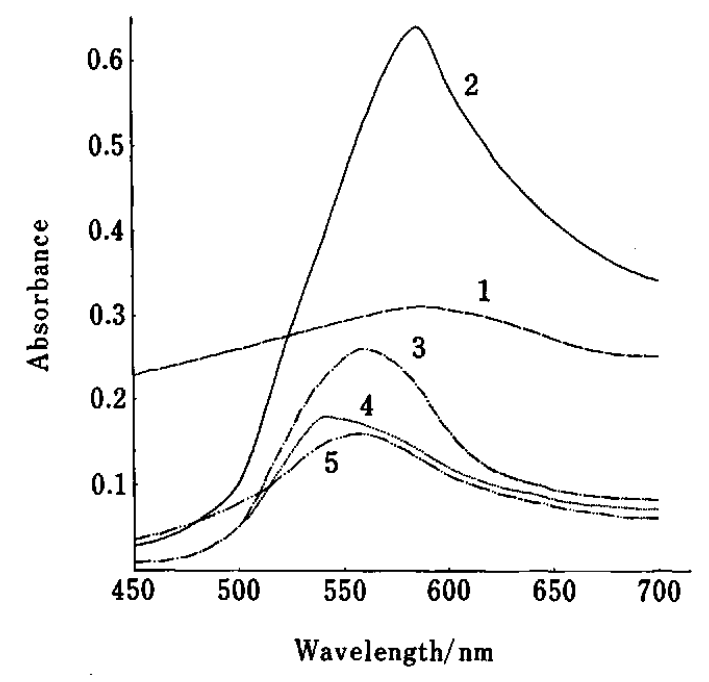

Fig. 1 Absorption spectra of the complex in the respective acids. (1) reagent blank against water; (2), (3), (4) and (5) ion association complex against reagent blank. Conditions: $\mathrm{Sc}, 2.0 \mu \mathrm{g} / 25 \mathrm{ml}$; PVA, $0.08 \%$; NB, $5.5 \times 10^{-5} \mathrm{~mol} \mathrm{dm}^{-3}$; molybdate, $6.8 \times 10^{-4} \mathrm{~mol} \mathrm{dm}^{-3}$; (2) $\mathrm{HClO}_{4}, 1.16 \mathrm{~mol} \mathrm{dm}^{-3}$; (3) $\mathrm{HNO}_{3}, 1.28 \mathrm{~mol} \mathrm{dm}^{-3}$; (4) $\mathrm{HCl}, 1.20 \mathrm{~mol} \mathrm{dm}^{-3}$; (5) $\mathrm{H}_{2} \mathrm{SO}_{4}$, $0.81 \mathrm{~mol} \mathrm{dm}^{-3}$.

with molybdate and Nile Blue is obtained in perchloric acid medium at $585 \mathrm{~nm}$. Hence, further studies were carried out at $585 \mathrm{~nm}$.

\section{Effect of inorganic acids}

Experiments showed that the color reaction could be performed in hydrochloric, nitric, sulfuric or perchloric acid media, but the sensitivities differed according to the acid used. The appropriate acidity range and absorptivity were as follows: $0.8-1.3 \mathrm{~mol} \mathrm{dm}^{-3}$ hydrochloric acid and $1.01 \times 10^{5} \mathrm{dm}^{3} \mathrm{~mol}^{-1} \mathrm{~cm}^{-1}$ at $540 \mathrm{~nm} ; 1.1-1.6$ mol dm ${ }^{-3}$ nitric acid and $1.46 \times 10^{5} \mathrm{dm}^{3} \mathrm{~mol}^{-1} \mathrm{~cm}^{-1}$ at $560 \mathrm{~nm} ; 0.7-1.1 \mathrm{~mol} \mathrm{dm}{ }^{-3}$ sulfuric acid and $9.0 \times 10^{4} \mathrm{dm}^{3}$ $\mathrm{mol}^{-1} \mathrm{~cm}^{-1}$ at $560 \mathrm{~nm} ; 0.9-1.4 \mathrm{~mol} \mathrm{dm}{ }^{-3}$ perchloric acid and $3.59 \times 10^{5} \mathrm{dm}^{3} \mathrm{~mol}^{-1} \mathrm{~cm}^{-1}$ at $585 \mathrm{~nm}$. The sensitivity was the highest in perchloric acid medium. Hence, $1.16 \mathrm{~mol} \mathrm{dm}^{-3}$ of the final concentration of perchloric acid was adopted in this work.

\section{Effect of molybdate}

Under the experimental conditions, a higher concentration of molybdate is required for complete formation of the molybdoscandic acid. The complex gave a maximum and almost constant absorbance in the range of $4.5 \times 10^{-4}-1.3 \times 10^{-3} \mathrm{~mol} \mathrm{dm}^{-3}$. In the procedure, $6.8 \times$ $10^{-4} \mathrm{~mol} \mathrm{dm}^{-3}$ molybdate (final concentration) was adopted.

\section{Effect of $N B$}

The sensitivity of the system depends upon the NB concentration. If it is too low, the decoloration rate is faster. If it is too concentrated, the reagent blank solution is deeply colored. Both extremes reduce the 
sensitivity of the color reaction system. The optimum concentration of NB was between $4.8 \times 10^{-5}-6.9 \times 10^{-5}$ mol dm$m^{-3} ; 5.5 \times 10^{-5} \mathrm{~mol} \mathrm{dm}^{-3}$ of NB was adopted.

\section{Effect of PVA}

In the absence of an enhacing agent or presence of an ionic surfactant, a precipitate forms in the system. In the presence of a non-ionic surfactant, such as polyethylene glycol octyl phenyl ether, Tween-80 or Triton X100 , the molar absorptivity of the system is lower. In the presence of a soluble high molecular compound, PVA, the molar absorptivity of the system is the highest. This result shows that PVA acts as an enhancing and solubilizing agent of the ion associate. Maximum absorbance was attained in the range of $0.04-0.16 \%$ $(\mathrm{w} / \mathrm{v})$. In the procedure, $0.08 \%(\mathrm{w} / \mathrm{v})$ PVA was adopted.

\section{Effect of temperature and stability of the complex}

At room temperature, the reaction of scandium with molybdate to form a heteropoly acid anion is extremely slow, but a higher temperature will increase the reaction rate. Experimentally, it was found that the reaction could be carried out by heating in a boiling water bath for at least $25 \mathrm{~min}$. In the general procedure, $30 \mathrm{~min}$ was adopted. Once the ion-association complex is formed, it will be stable for at least $8 \mathrm{~h}$.

\section{Calibration graph and sensitivity}

Under the optimum conditions, a linear calibration graph was obtained over the range $0-2.0 \mu \mathrm{g}$ of scandium in $25 \mathrm{ml}$ of solution. The calibration graph was represented as $A=0.3197 C+0.0066(r=0.9990)$, where $A$ is the absorbance at $585 \mathrm{~nm}, C$ the amount $(\mu \mathrm{g})$ of $\mathrm{Sc}$ in $25 \mathrm{ml}$ and $r$ the correlation coefficient. The molar absorptivity was $3.59 \times 10^{5} \mathrm{dm}^{3} \mathrm{~mol}^{-1} \mathrm{~cm}^{-1}$ and Sandell's sensitivity was $0.13 \mathrm{ng} \mathrm{cm}^{-2}$. The limit of detection, calculated as three times of the standard deviation of the blank, was $3.0 \mathrm{ng} \mathrm{ml}^{-1}(n=7)$. The relative standard deviation of the determination of $1.0 \mu \mathrm{g}$ of scandium was found to be $2.8 \%(n=10)$.

\section{Effect of foreign ions}

The solutions containing $1.0 \mu \mathrm{g}$ of scandium in $25 \mathrm{ml}$ and various amounts of rare earths were prepared and the general procedure was followed for the determination of scandium. The tolerable limits are shown in Table 1. This shows that 10 -fold amounts of rare earths, except cerium, are tolerable. The results in the presence of 39 possibly accompanying ions (5\% error maximum) are summarized in Table 1. Most of the ions have no influence, but equal amounts of $\mathrm{SiO}_{3}{ }^{2-}, \mathrm{Sb}^{3+}, \mathrm{As}(\mathrm{V})$, $\mathrm{Ti}(\mathrm{IV})$ and $\mathrm{Zr}(\mathrm{IV})$ interfere seriously. Hence, scandium was separated using solvent extraction in the analysis of geological samples containing these elements.

\section{Composition of the complex}

The ratio of scandium to NB in the ion-association complex was determined by both mole-ratio and
Table 1 Tolerated amounts of foreign ions in the determination of scandium ${ }^{\mathrm{a}}$

\begin{tabular}{lc}
\multicolumn{1}{c}{ Foreign ion } & $\begin{array}{c}\text { Tolerated } \\
(\mu \mathrm{g} / 25 \mathrm{ml})\end{array}$ \\
\hline $\mathrm{SO}_{4}{ }^{2-}, \mathrm{C}_{2} \mathrm{O}_{4^{2-}}$ & 4000 \\
$\mathrm{Mg}^{2+}$ & 3000 \\
$\mathrm{Ca}^{2+}, \mathrm{NO}_{3}{ }^{-}, \mathrm{Cl}^{-}, \mathrm{Br}^{-}, \mathrm{I}^{-}$ & 2000 \\
$\mathrm{Thiourea}^{-} \mathrm{F}^{-}$ & 1000 \\
$\mathrm{Co}^{2+}$ & 500 \\
$\mathrm{Zn}^{2+}$ & 400 \\
$\mathrm{Al}^{3+}, \mathrm{Fe}^{3+}, \mathrm{Mn}^{2+}, \mathrm{Cu}^{2+}, \mathrm{Pb}^{2+}$ & 100 \\
$\mathrm{Hg}^{2+}, \mathrm{B}(\mathrm{III}), \mathrm{V}(\mathrm{V})$ & 50 \\
$\mathrm{Cr}^{3+}, \mathrm{Cr}(\mathrm{VI}), \mathrm{Bi}{ }^{3+}, \mathrm{Se}(\mathrm{IV}), \mathrm{U}(\mathrm{VI}), \mathrm{RE}^{\mathrm{b}}(\mathrm{III})$ & 10 \\
$\mathrm{Ag}^{+}, \mathrm{Ni}{ }^{2+}, \mathrm{P}(\mathrm{V}), \mathrm{Ce}(\mathrm{III})$ & 5 \\
$\mathrm{~W}(\mathrm{VI})$ & 3 \\
$\mathrm{Tl}^{+}, \mathrm{Ga}(\mathrm{III})$ & 2 \\
$\mathrm{Ce}(\mathrm{IV})$ & 0.5 \\
\hline
\end{tabular}

a. Scandium, $1.0 \mu \mathrm{g} / 25 \mathrm{ml}$.

b. RE: La, Pr, Nd, Sm, Eu, Gd, Tb, Dy, Ho, Er, Tm, Lu, Y.

equilibrium shift method. Both results showed that the ratio of $S c$ to NB is $1: 3$. In order to establish the ratio of Sc to Mo in the complex, a crystal of the ionassociation complex, which was prepared in the general procedure but omitting PVA, was ignited in a corundum crucible at $873 \mathrm{~K}$ for $1 \mathrm{~h}$. After cooling, the residue was transferred to a $50-\mathrm{ml}$ beaker, $5 \mathrm{ml}$ of $1 \%(\mathrm{w} / \mathrm{v})$ sodium hydroxide was added, and we evaporated the solution to incipient dryness; then $5 \mathrm{ml}$ of $6 \mathrm{~mol} \mathrm{dm}^{-3}$ nitric acid was added, and we evaporated the solution to dryness. The soluble salts were dissolved with $0.1 \mathrm{~mol} \mathrm{dm}^{-3}$ nitric acid, then the solution was transferred to a $25-\mathrm{ml}$ volumetric flask, and diluted to the mark with $0.1 \mathrm{~mol} \mathrm{dm}^{-3}$ nitric acid and contents mixed well. Scandium and molybdenum in the solution were determined by Chlorophosphonazo- $p$ - $\mathrm{Cl}^{5}$ and 4,5-dibromophenylfluorone meth$\mathrm{od}^{14}$, respectively. The results show that the ratio of $\mathrm{Sc}$ to Mo is $1: 12$. Hence the $\mathrm{Sc}: \mathrm{Mo}: \mathrm{NB}$ is $1: 12: 3$.

The IR spectra of the prepared crystal and the pure NB were compared. A spectral comparison showed both spectra to be very similar above $1200 \mathrm{~cm}^{-1}$, which is characteristic of the NB cations. The differences between both spectra were marked below $1200 \mathrm{~cm}^{-1}$, because both the anions were different. For the complex, the absorption peaks at 1125 and $1080 \mathrm{~cm}^{-1}$ became broad and strong; four new peaks appeared at 910,790, 630 and $385 \mathrm{~cm}^{-1}$. These are characteristics of Sc-O and Mo-O covalent bonds, and show that the ion-association bands are formed between NB cations and molybdoscandic acid anions.

\section{Application to the geological samples}

The proposed method was applied to the determination of scandium in some geological samples. The results obtained are given in Table 2, from which it can be seen that the recoveries are satisfactory and the results agree well with the standard values. 
Table 2 Results for the determination of scandium in geological samples

\begin{tabular}{cccc}
\hline Sample & Standard value, $\%$ & Found, $\%$ & RSD, $\%$ \\
\hline GSR-1 & 0.00061 & 0.00062 & 5.5 \\
GSS-4 & 0.00202 & 0.0022 & 1.7 \\
GSS-7 & 0.0028 & 0.0029 & 1.6 \\
GSD-9 & 0.00111 & 0.00133 & 3.9 \\
\hline
\end{tabular}

Table 3 Comparison of the sensitivities of the determination of scandium

\begin{tabular}{llcc}
\hline \multicolumn{1}{c}{ Reagent } & $\lambda_{\max } / \mathrm{nm}$ & $\begin{array}{c}\varepsilon \times 10^{4} / \mathrm{dm}^{3} \\
\mathrm{~mol}^{-1} \mathrm{~cm}^{-1}\end{array}$ & Ref. \\
\hline Xylenol Orange & $555-560$ & 2.9 & 1 \\
Arsenazo III & 675 & 1.9 & 2 \\
Eriochrome Azurol B & 650 & 9.85 & 3 \\
Chromazurol S & 610 & 15.0 & 4 \\
Chlorophosphonazo- $p$-Cl & 762 & 15.4 & 5 \\
5-Br-PADAP & 595 & 12.0 & 6 \\
4,5-Dibromophenyl- & & & 7 \\
$\quad$ fluorone & 590 & 22.6 & 8 \\
Methylthymol Blue & 615 & 25.0 & this work \\
Nile Blue & 585 & 35.9 & \\
\hline
\end{tabular}

A comparison of the sensitivities for the determination of scandium by various methods is shown in Table 3 . Obviously, the sensitivity and selectivity of the method are superior to those of other published methods.

This work was supported by the Natural Sciences Foundation of Yunnan, China.

\section{References}

1. S. S. Berman, G. R. Duval and D. S. Russell, Anal. Chem., 35, 1392 (1963).

2. S. B. Savvin, Talanta, 8, 673 (1961).

3. C. Vekhande and K. N. Munshi, Microchem. J., 23, 28 (1978).

4. M. Jarosz and Z. Marczenko, Anal. Chim. Acta, 159, 309 (1984).

5. W. R. Chen, J. M. Pan, C. G. Hsu and S. S. Ge, Mikrochim. Acta [Wien], 1985 III, 417.

6. X. K. Wang, Fenxi Huaxue, 19, 297 (1991).

7. D. J. Wang, J. Y. Wu, J. Y. Zhuang, X. Chen and W. Q. Zhong, Yankuang Ceshi, 13(3), 180 (1994).

8. W. Lin and P. Zhang, Fenxi Shiyanshi, 5(11), 57 (1986).

9. Z. B. Li and Q. H. Xu, Fenxi Huaxue, 20, 520 (1992).

10. Z. B. Li, J. L. Wang and Q. H. Xu, Fenxi Huaxue, 21, 639 (1993).

11. Z. B. Li, J. L. Wang and Q. H. Xu, Mikrochim. Acta, 116, 219 (1994).

12. J. L. Wang, Z. B. Li and Q. H. Xu, Anal. Lett., 28, 147 (1995).

13. Z. B. Li, J. L. Wang and Q. H. Xu, Mikrochim. Acta, 118, 43 (1995)

14. S. F. Yang, Fenxi Shiyanshi, 4(2), 19 (1985).

(Received July 25, 1995)

(Accepted December 18, 1995) 